\title{
MICRO-UTOPIAS IN ARCHITECTURE
}

\section{A B S T R A C T}

In recent years, new formats of socially engaged architectural practices have become increasingly present in the urban space. Projects of temporary use, mostly erected by transdisciplinary working collectives, have become part of a broader trend, marking a social turn in architecture.

In this paper, these practices are understood as a concrete aesthetic and political phenomenon that brings about alternative forms of social coexistence: micro-utopias arise against the backdrop of urban neo-liberalisation processes. The history of utopia, and particularly the utopian tradition in architecture, facilitate to put this argument forward.

\section{Sandra Meireis}




\section{INTRODUCTION}

Since the 1990s, socially engaged architectural practices have multiplied, e. g. architectures of temporary use have become increasingly present in the urban space against the backdrop of neo-liberalisation processes. Such projects are typically small-scale and characterised by their formal imperfection and conflict potential. Not only does the interplay with the external conditions create friction and resistance, also the inner, original motives are characterised by divergences and contradictions. In these projects, both the search for alternative future visions, understood as critique of the real, and an idealistic, socially romantic escapism is inscribed. This inherent dialectic is symptomatic for the genre of utopia, which is here considered a cultural technique and applied as a critical theoretical approach.

Following the history of utopian thought, especially in its architectural tradition, new socially engaged architectural practices and the experimental nature of its spatial production are presented in more detail. This critical approach towards urban design is understood as a new manifestation of the utopian notion and, in turn, reflects current tendencies in social development.

\section{MILESTONES IN THE HISTORY OF UTOPIAN THOUGHT}

In utopian research, the way of examining utopias is twofold. On the one hand, there is the historical-critical analysis, and on the other, there is the more general, hence fundamental question for the basic function of utopias in societies. In the historical-critical analysis, the focus is on the question of why and how do respective utopian concepts emerge and manifest themselves in a certain manner, thus the historical moment and specific context of the appearance of each utopia particularly matters.

From its very beginnings in antiquity, namely Plato, utopian thinking has always been closely linked to the search for the ideal state and its political condition. While the ideas and writings of utopian authors in the Renaissance (e. g. Thomas More) and the Age of Enlightenment (e. g. Denis Vairasse) were in this sense solely didactical, the proceedings of the French Revolution at the end of the eighteenth century suggested that the course of history could be redirected through the implementation of a certain utopian ideal; in this case, shortly, the abolition of feudalism. Accordingly, in the history of utopia Louis-Sébastian Mercier's work L'An 2440 (1771) marks a practical turn. ${ }^{1}$ In other words, from then on it was believed that abstract ideals could become reality driven by conscious human action. This is also an explanation why in 
the nineteenth century, utopian socialists such as Charles Fourier and Robert Owen developed their ideas full of optimism and activism. ${ }^{2}$ In reaction to them and to the changing living conditions under the process of industrialisation in England, Karl Marx und Friedrich Engels took a critical stance towards the classical utopian thinking; set forth by Engels in his essay The Development of Socialism from Utopia to Science (1880). Thus, the different ways how utopias appear and get perceived vary in accordance with historical incidents.

At the centre of modern utopian research is the functional - in contrast to the historical - reading of utopias. The aim here is to question utopia for its superordinate social function. For example, Reinhart Koselleck assigns utopia an anthropological function that contrasts the historicising and ideologising exegesis. $^{3}$ Similarly, Norbert Elias says that utopias are "directional fantasyimages of possible futures", indispensable as a means of orientation in human societies. The image shows either what kind of solutions to social problems or type of society its authors desire to come about (wish images) or what solutions or futures they fear (fear images) '. ${ }^{4}$ Generally speaking, utopia orientates in considerations of coping with conflicts in the society of their origin. ${ }^{5}$ The analyses of the social function of utopia is also at the centre of Alexander Neupert-Doppler's research, who finds utopian perspectives, especially in social movements. ${ }^{6}$ In her recent book Utopia as a Method, Ruth Levitas reassigns architecture a special role in the social function of utopian conceptions. ${ }^{7}$

\section{THE UTOPIAN TRADITION IN ARCHITECTURE}

While the spatial representation of utopias in the Renaissance was of a symbolic character, e. g. Ambrosius Holbein's woodcut print for Thomas More's Utopia (revised Froben edition, Basel 1518), later in the nineteenth century the architectural representation of utopian concepts became an expression of its inner logic (e. g. Chaux, Claude-Nicolas Ledoux, 1771-93), and thereby visualised the society's ideals they arose from; a time when utopia discarded the paternalism through the literary medium. From then on, architecture and utopian thinking intertwined stronger than ever before. In the history of architecture, utopian ideals periodically oscillate between a belief in the future in harmony with nature and the future liberated by the progress of technology.

Among one of the first representatives of the modernist call for a harmonious life in light, air and sun is Ebenezer Howard who initiated the Garden City Movement with his work Garden Cities of To-morrow (1898). In contrast, the period leading to the twentieth century is marked by the visions of the 
Italian futurists, namely Tommaso Marinetti and Antonio Sant'Elia, who were - comparable to the utopian socialists - enthusiastic about the technological progress and believed this would add to the betterment of life quality. ${ }^{8}$ Later, as a testimony to scepticism about technology in the purification process of the early Weimar Republic, Walter Gropius in his manifesto and program of the Staatliches Bauhaus Weimar (1919) called for a return to craftsmanship. Influenced by the life reform movement, the Bauhaus oscillated in the early phase "between social romanticism and utopian surplus."

Today, the large-scale utopias of the 1920-30s, e. g. Le Corbusier's urban vision Ville Radieuse (1924/1933) or Frank Lloyd Wright's rural reorganisation Broadacre City $(1932)^{10}$ are associated with the totalitarian horrors of the classic modernist period. In reaction, the events of the 1960-70s came about with a great will to reform, e. g. through the activities of the Team 10 protagonists. These so-called structuralist projects happened in a temporal overlap with the emergence of technicist architectural visions and urban megastructures, which are usually first and foremost associated with the utopian topic in architecture.

\section{EXPERIMENTAL SPATIAL PRODUCTION ${ }^{11}$}

Typical sites for the emergence of contemporary utopias - micro-utopias in the guise of temporary architectural projects, as argued below - are blank spaces, empty places, derelict areas, vacant lands, spaces of uncertainty, domains in abeyance, mostly publicly accessible, e. g. inner-city wastelands. They particularly appear in transition phases of power or governance, in temporary vacuums of decision-making. Examples of this are the transient state of Berlin after the fall of the wall or the fabric of Belgrade or Zagreb after the collapse of Yugoslavia. ${ }^{12}$ Thus, the circumstance of the temporary is a key feature of the formation conditions of such projects, and in the same time determines their small scale. Some of them appear like open, permeable and interchangeable spacious thresholds, others are of greater solidity. Their aesthetic characteristics (scale, construction, and materiality) are mostly of an experimental nature. Often the initiators prefer to work with raw materials, readily available, easy to machine, cost-effective and recyclable, understood as a commitment to an ecological consciousness. Although the initial conditions for their creation are highly diverse (depending on the context, method, and format), participation strategies usually play a crucial role in the design process. The social interaction between the partaking people takes centre stage, meaning the socially engaged citizen becomes the protagonist in the overall setting. 
Temporary architectures are realised informally, as well as in the context of architecture and art festivals. ${ }^{13}$ Subsequent debates and project catalogues reflect on their specific nature. ${ }^{14}$

A part of the younger generation of architects dedicates itself to this 'movement'. Practitioners from the fields of architecture, design, and art collaborate with scientists such as geographers and sociologists, altogether forming different research and design collectives. ${ }^{15}$ They appear as initiating and internationally working agents, understanding their activity as an expression of an integrative practice, favour transdisciplinary ${ }^{16}$ and non-hierarchical teamwork over traditional office work organisation models and thus are critical of the slowness of the classical architectural process and the dependency on economic decisions.

The interest of architects in social and performative techniques overlaps with areas of the arts and sciences. In art, such strategies are mainly concerned with relational tactics, i.e. the connection of human action and space-forming matter. Here, the artists' authorship only has a catalytic function. This opposes the traditional understanding of an art work as autonomous, self-referential object presented in white-cube spaces. ${ }^{17}$

In the sciences, the research areas concerned with urbs (urban space) and civitas (civil activities) are of special interest here, e. g. the critical urban studies, which give priority to the socio-political program over space-forming substances, often in the context of right-to-city debates, with Henri Lefebvre and David Harvey as key references. The social relevance of alternative urban practises is reflected in a myriad of conferences ${ }^{18}$ and academic writings. ${ }^{19}$

In the architectural discourse, as in art, participatory strategies stand in contrast to the notion of the autonomous object. ${ }^{20}$ Historical references can be found in the context of "structuralism", pointing to a development that has sensitised to the self-empowerment of the users since the 1960/70s.

\section{CRITICAL URBAN DESIGN}

The development of temporary use in architecture is only recently identified as part of a broader trend in architecture and urban design towards a more socially engaging practice. Major exhibitions $\mathrm{s}^{21}$ and awards $\mathrm{s}^{22}$ were dedicated to the subject that some refer to as a social turn in architecture. Generally, in the debates on the topic, the demand for urban commons is of utmost interest. Accordingly, the discussion about forms of civic self-organisation figures 
prominently. In this regard, a recurring topic is the collective urban gardening. Its success is attributable to various aspects such as the opportunity to meet locals and spend leisure time in a non-commercial environment. It represents a grassroots organisation model that welcomes strangers who want to work with each other and with nature, it is a low-threshold gathering place, complementary to the omnipresence of the digital.

A good example of this is Berlin's Prinzessinnengarten: In 2009 it began as a registered guerrilla garden on a vacant pocket of land at Moritzplatz. Since then the project has become an urban gardening pilot project, including a garden kitchen with a coffee bar, a gardener's workshop, a library and a "neighbourhood academy" where knowledge exchange on cultural practices takes place, as much as educational activities on organic food production, biodiversity and climate protection are offered; supervised by a dozen employees (of Nomadisch Grün gGmbH, and since 2013 supported by Common Grounds e. V) and one thousand volunteers sharing responsibilities. ${ }^{23} \mathrm{Up}$ to this day, the project is tolerated until further municipal decisions have been taken.

In general, a given time limit is primarily perceived as potential for the construction of experimental architectures for temporary use. The relativism of temporality is therefore considered a key element in debates on alternative urban design. ${ }^{24}$

The indefinite but permanent threat of closure slowly erodes the belief in the project's survival, as in the following case: In their project R-Urban: Practices and Networks of Urban Resilience in Colombes, Paris, the initiators of the Atelier d'Architecture Autogérée attempted to challenge entrenched urban structures, e. g. the traditional city-country dualism. During the 10-year project phase, a socio-ecological cultural landscape was set up, including an independent economic cycle. The initiators focused on local production and distribution cycles that included three prototypical, community operated units: 1) an ecological housing cooperative, 2) a micro-farm with educational spaces, and 3) a greenhouse with recycling unit.

This kind of civic-economic organisation shows different and ambivalent relationships of dependency to the official municipal politics, primarily regarding the urban basic infrastructure, citizen engagement, land politics, and not least the city's marketing strategies. ${ }^{25}$ In any case, currently a recognisable shift takes place in the relationship between creative disciplines and urban politics. Correspondingly, the current Berlin Senate building director Regula Lüscher 
asks whether art, architecture and civil planning interrelate productively to each other in the discourse on the future of urban space, or whether they meet in opposition and rivalry?26 If the aim is a socially sustainable urban development, the combination of bottom-up organisation and top-down planning is ultimately required, however this may look in individual cases.

\section{CONCLUSION}

Micro-utopias emerge from a critical preoccupation with the present and develop a utopian consciousness. They are field experiments for alternative scenarios, e. g. socially-oriented economics. Such initiatives exist because they engage with the "currency of post-capitalism" 27 , which are: leisure, network activity, and other freely available goods such as knowledge. Scenarios of a post-growth society are imagined - as halting or inefficient as it may seem at first. So far serious efforts are lacking in other areas.

But these projects also include other primordial utopian topics, updated in a contemporary manner: It is thematised and criticised that democratic standards and basic rights such as the freedom of speech, movement and assembly, political participation, and the right to inclusion and diversity, among other things, are tied to the public sphere, threatened by the ever-increasing privatisation of public space. Combining the best of all possible worlds, the combination of the digital culture in a natural environment without playing them off against each other, could create new forms of participation in a just city.

Accordingly, take the listed project catalogues as directories to hand, imagine a globe on which you mark their geographical places of appearance, then a global net would spread over cities, countries and continents. Local contradictions and efficiencies would come into the picture.

The physical appearance of such critical-spatial structures can be identified as a framework for action in the public, thus political space. In that sense, the success of individual projects is secondary, what matters is the overall phenomenon and its constant sensitisation to desire or fear. Micro-utopias are globally active, highly diverse and contradictory. The manifestation of the critical utopian discourse has changed and expanded. 

architektonischer Minimaltechniken (working title) are presented. zur neuzeitlichen Utopie, Vol. 3, ed. Wilhelm Voßkamp (Stuttgart: Metzler, 1982), 1-14. cf. Barbara Goodwin, and Keith Taylor. The Politics of Utopia (London/UK: Hutchinson, 1982). cf. Koselleck, "Verzeitlichung der Utopie," 1-14.

Norbert Elias as cited in Richard Kilminster. "The debate about Utopias from a sociological perspective," Human Figurations 3, no. 2 (2014). doi: http://hdl.handle.net/2027/ spo.11217607.0003.203.

cf. Ernst Bloch. The Principle of Hope, Vol. 1 and 2 (Cambridge/Mass.: MIT Press, 1986); Richard Saage "Wie zukunftsfähig ist der klassische Utopiebegriff?," UTOPIE kreativ 165/166 (2004): 617-636. http://www.rosa-luxemburg-club.de/fileadmin/rls uploads/pdfs/165 166-saage.pdf. 
cf. Ruth Levitas. Utopia as a Method. The Imaginary Reconstitution of Society (Hampshire/UK: Palgrave Macmillan, 2013).

cf. Ruth Eaton. Ideal Cities: Utopianism and the (Un)Built Environment (London/UK: Thames and Hudson, 2007).

Anja Baumhoff and Holm Friebe in a discussion with Ellen Blumenstein, Arch+ features 36: Bauhaus project. Design as a social experiment. KW Institute for Contemporary Art, Berlin, March 26, 2015. See http://www.archplus.net/home/news/7,1-11395,1,0.html. Accessed: June 6, 2017.

cf. Robert Fishman. Urban Utopias in the Twentieth Century: Ebenezer Howard, Frank Lloyd Wright, Le Corbusier (New York/NY: Basic Books, 1977).

Differently used terms and designations circulate such as temporary and mobile architecture, projects and interventions for temporary use, urban acupuncture, pop-up, ad-hoc, DIY and makeshift urbanism, ephemeral urbanism, alternative urban practices, etc. In its entirety, best to grasp with e. g. critical urban design through experimental spatial production.

In urban planning, the term 'urban commons' is well-known when it comes to projects that are characterised by grassroots organisation and bottom-up development.

cf. Klaus Overmeyer, Holger Lauinger, and Senatsverwaltung für Stadtentwicklung Berlin. Urban Pioneers. Temporary Use and Urban Development in Berlin (Berlin: Jovis, 2007); Ana Jeinic. "Neoliberalism and the Crisis of the Project... in Architecture and Beyond," in Is there (anti-) neoliberal Architecture?, ed. Ana Jeinic, and Anselm Wagner (Berlin: Jovis, 2013), 64-77.

To name a few: Todays Art Festival, The Hague, Netherlands, which takes place annually since 2005; Urban Dreams, Plovdiv, Bulgarien, 2012; MakeCity. A Festival for Architecture and Urban Alternatives, Berlin, 2015 and 2018; London Festival of Architecture, which started in 2004, 'community' its theme in 2016.

cf. Nishat Awan, Tatjana Schneider and Jeremy Till. Spatial Agency. Other Ways of Doing Architecture (Oxon/UK: Routledge, 2011); Bryan Bell, and Katie Wakeford. Expanding Architecture. Design as Activism (New York: Metropolis, 2008); Francesca Ferguson, and Urban Drift Projects. Make_Shift City. Renegotiating the Urban Commons (Berlin: Jovis, 2014); Jesko Fezer, and Mathias Heyden. Hier entsteht. Strategien partizipativer Architektur und räumlicher Aneignung (Berlin: b_books, 2004); Elke Krasny. Hands-on Urbanism 1850-2012. Vom Recht auf Grün (Wien: Turia + Kant, 2012); Rahul Mehrotra, and Felipe Vera. Ephemeral Urbanism. Does permanence matter? (Trento: List, 2017); Philipp Oswalt, Klaus Overmeyer, and Philipp Misselwitz. Urban Catalyst. The Power of Temporary Use (Berlin: DOM, 2013); Cate St. Hill. This Is Temporary: How Transient Projects Are Redefining Architecture (Newcastle upon Tyne/UK: RIBA publishing, 2016).

To name a few: 72 Hour Urban Action, Actopolis, Andrés Jaque/Office for Political Innovation, Assemble Collective, Atelier d'Architecture Autogérée, Basurama Asociación, Collectif Bellastock, CooperativeCity/Eutropian, Exyzt, muf architecture/art, Nomadisch Grün, RaumlaborBerlin, Refunc NL, Rural Studio, Stadtlücken e. V., ONOFF, Umschichten, Urban Catalyst, etc.

Transdisciplinarity is understood here as a special, integrative form of interdisciplinarity for which the overcoming of disciplinary boundaries is just as central as the connection between science and practice, cf. Rico Defila, and Antonietta Di Giulio. "Interdisziplinarität und Disziplinarität, " in Zwischen den Fächern - über den Dingen? Universalisierung versus Spezialisierung akademischer Bildung, ed. Jan H. Olbertz (Wiesbaden: Springer VS, 1998), 111-137.

cf. Claire Bishop. "The Social Turn: Collaboration and Its Discontents," Artforum 44, no. 6 (2006): 178-183. https://www.gc.cuny.edu/CUNY_GC/media/CUNY-Graduate-Center/PDF/Art\%20 Hist ory/Claire\%20Bishop/Social-Turn.pdf; Nicolas Bourriaud. Relational Aesthetics (Dijon: Les presses du reel, 2002); Stella Rollig, and Eva Sturm. Dürfen die das? Kunst als sozialer Raum (Wien: Turia + Kant, 2002).

To name a few: Make_Shift: the expanded field of critical spatial practice, international conference at the Institute for Architecture, TU Berlin, Oct. 2012; Designed to Improve? Buildings, interventions and the making of the ,social' in interdisciplinary urban practices, international and interdisciplinary workshop at the Institute of Human Movement Science, University of Hamburg, May 2014; etc. 
cf. Paola Alfaro d'Alençon, Bettina Bauerfeind, and Daniela Konrad. Ephemere Stadtentwicklung. Planungshilfe und Handbuch (Berlin: DOM, 2017); Harriet Hawkins. "Geography and Art. An expanding field: Site, the body and practice," Progress in Human Geography 37, no. 1 (2012): 5271. doi: 10.1177/0309132512442865; David Graeber. "The New Anarchists," New Left Review 13 (2002): 61-73. https://newleftreview.org/II/13/david-graeber-the-new-anarchists; Sarah Kumnig, Marit Rosol, and Andreas Exner. Umkämpftes Grün. Zwischen neoliberaler Stadtentwicklung und Stadtgestaltung von unten. (Bielefeld: transcript, 2017); Fran Tonkiss. "Austerity Urbanism and the Makeshift City,” City 17, no. 3 (2013): 312-324. doi: 10.1080/13604813.2013.795332.

cf. Ingo Bohning. „Autonome Architektur“ und „partizipatorisches Bauen“. Zwei Architekturkonzepte (Zürich: Eidgenössische Technische Hochschule, Dissertation, 1981).

The $15^{\text {th }}$ International Architecture Biennale in Venice 2016 is a good example of this development. Under the title "Reporting from the Front", the main curator Alejandro Aravena, a Chilean architect who was recently awarded with the Pritzker Prize, brought together projects that face the ecological and economic challenges of the $21^{\text {st }}$ century globally, combining pragmatic action with aesthetic aspirations.

The curator and architectural historian Andres Lepik sets different priorities within the theme, presented in the following exhibition series: Small Scale Big Change. New Architectures of Social Engagement (MoMA, N.Y. 2010), Think Global, Build Social! Architectures for a Better World (DAM, Frankfurt/M. 2013), Afritecture. Building with the Community (TUM, Munich 2013/14) and Does Permanence Matter? Ephemeral Urbanism (TUM, Munich 2017); etc.

In 2015, the British Turner Prize (for art) was awarded to the Assemble Collective; in 2016, the Pritzker Prize ('Nobel Prize' in architecture) went to Alejandro Aravena; the Austrian FriedrichKiesler Award (for 'correlated arts') went to Andrés Jaque/Office for Political Innovation; and the Julius Berger Prize (for urban development) was dedicated to the initiative ExRotaprint in Berlin. cf. Ferguson, Make_Shift City.

cf. Jesko Fezer. Civic City Cahier 6: Design In and Against the Neoliberal City (London/UK: Bedford Press, 2013); Marit Rosol. "Community Volunteering as Neoliberal Strategy? Green Space Production in Berlin," Antipode 44, no. 1 (2012): 239-257. doi:10.1111/j.1467-8330.2011.00861.x. cf. Regula Lüscher. "Preface," in Make_Shift City, ed. Ferguson, 8-9.

Paul Mason. "The End of Capitalism Has Begun," Guardian, July 17, 2015. https://www. theguardian.com/books/2015/jul/17/postcapitalism-end-of-capitalism-begun. 
Alfaro d'Alençon, Paola, Bettina Bauerfeind, and Daniela Konrad. Ephemere Stadtentwicklung. Planungshilfe und Handbuch. Berlin: DOM, 2017.

Awan, Nishat, Tatjana Schneider and Jeremy Till. Spatial Agency. Other Ways of Doing Architecture. Oxon/UK: Routledge, 2011.

Bell Bryan, and Katie Wakeford. Expanding Architecture. Design as Activism. New York: Metropolis, 2008.

Bishop, Claire. "The Social Turn: Collaboration and Its Discontents." Artforum 44, no. 6 (2006): 178-183. https://www.gc.cuny.edu/CUNY GC/media/CUNY-Graduate-Center/PDF/Art\%20Hi story/Claire\%20Bishop/Social-Turn.pdf. Accessed: July 2017

Bloch, Ernst. The Principle of Hope, Vol. 1 and 2. Cambridge/Mass.: MIT Press, 1986 [German 1959].

Bohning, Ingo., ,Autonome Architektur “ und ,partizipatorisches Bauen “. Zwei Architekturkonzepte. Zürich: Eidgenössische Technische Hochschule, Dissertation, 1981.

Bourriaud, Nicolas. Relational Aesthetics. Dijon: Les presses du reel, 2002 [French 1998].

Defila, Rico, and Antonietta Di Giulio. "Interdisziplinarität und Disziplinarität.“ In Zwischen den Fächern-über den Dingen? Universalisierung versus Spezialisierung akademischer Bildung, edited by Jan H. Olbertz, 111-137. Wiesbaden: Springer VS, 1998.

Eaton, Ruth. Ideal Cities: Utopianism and the (Un)Built Environment. London/UK: Thames and Hudson, 2007 [2001].

Elias, Norbert. "Thomas More's Critique of the State: With Some Thoughts on a Definition of the Concept of Utopia.” In The Collected Works, Essays 1, Vol. 14. Dublin: UCD Press, 2009 [German 1982].

Engels, Friedrich "Socialism: Utopian and Scientific." In Marx/Engels Selected Works, Vol. 3 (1880): 95-151. https://www.marxists.org/archive/marx/works/1880/soc-utop/index.htm. Accessed: Jan. 2018

Ferguson, Francesca, and Urban Drift Projects. Make_Shift City. Renegotiating the Urban Commons. Berlin: Jovis, 2014.

Fezer, Jesko, and Mathias Heyden. Hier entsteht. Strategien partizipativer Architektur und räumlicher Aneignung. Berlin: b_books, 2004.

Fezer, Jesko. Civic City Cahier 6: Design In and Against the Neoliberal City. London/UK: Bedford Press, 2013.

Fishman, Robert. Urban Utopias in the Twentieth Century: Ebenezer Howard, Frank Lloyd Wright, Le Corbusier. New York/NY: Basic Books, 1977.

Goodwin, Barbara, and Keith Taylor. The Politics of Utopia. London/UK: Hutchinson, 1982.

Graeber, David. "The New Anarchists.” New Left Review 13 (2002): 61-73. https://newleftreview. org/II/13/david-graeber-the-new-anarchists. Accessed: July 2017.

Hawkins, Harriet. "Geography and Art. An expanding field: Site, the body and practice." Progress in Human Geography 37, no. 1 (2012): 52-71. doi: 10.1177/0309132512442865. Accessed: Jan. 2018.

Jeinic, Ana. "Neoliberalism and the Crisis of the Project... in Architecture and Beyond." In Is there (anti-)neoliberal Architecture?, edited by Ana Jeinic, and Anselm Wagner, 64-77. Berlin: Jovis, 2013.

Kilminster, Richard "The debate about Utopias from a sociological perspective." Human Figurations 3, no. 2 (2014 [German 1982]). doi: http://hdl.handle.net/2027/spo.11217607.0003.203. Accessed: Jan. 2018. 
Koselleck, Reinhart. „Verzeitlichung der Utopie.“ In Utopieforschung. Interdisziplinäre Studien zur neuzeitlichen Utopie, Vol. 3, edited by Wilhelm Voßkamp, 1-14. Stuttgart: Metzler, 1982.

Krasny, Elke. Hands-on Urbanism 1850-2012. Vom Recht auf Grün. Wien: Turia + Kant, 2012.

Kumnig, Sarah, Marit Rosol, and Andreas Exner. Umkämpftes Grün. Zwischen neoliberaler Stadtentwicklung und Stadtgestaltung von unten. Bielefeld: transcript, 2017.

Levitas, Ruth. Utopia as a Method. The Imaginary Reconstitution of Society. Hampshire/UK: Palgrave Macmillan, 2013.

Lüscher, Regula. "Preface.” In Make_Shift City. Renegotiating the Urban Commons, edited by Francesca Ferguson, and Urban Drift Projects, 8-9. Berlin: Jovis, 2014.

Mason, Paul. "The End of Capitalism Has Begun.” Guardian, July 17, 2015. https://www. theguardian.com/books/2015/jul/17/postcapitalism-end-of-capitalism-begun. Accessed: July 17 2015.

Mehrotra, Rahul, and Felipe Vera. Ephemeral Urbanism. Does permanence matter? Trento: List, 2017.

Neupert, Alexander, and Lisa Doppler. „Das Recht auf Stadt als konkrete Utopie? Utopisches Bewusstsein als Gegenstand der Bewegungsforschung.“ In Stadt und soziale Bewegungen, edited by Norbert Gestring et al., 163-178. Wiesbaden: Springer, 2014.

Neupert-Doppler, Alexander. Utopie. Vom Roman zur Denkfigur. Stuttgart: Schmetterling, 2015.

Oswalt, Philipp, Klaus Overmeyer, and Philipp Misselwitz. Urban Catalyst. The Power of Temporary Use. Berlin: DOM, 2013.

Overmeyer, Klaus, Holger Lauinger, and Senatsverwaltung für Stadtentwicklung Berlin. Urban Pioneers. Temporary Use and Urban Development in Berlin., Berlin: Jovis, 2007.

Rollig, Stella, and Eva Sturm. Dürfen die das? Kunst als sozialer Raum. Wien: Turia + Kant, 2002.

Rosol, Marit. "Community Volunteering as Neoliberal Strategy? Green Space Production in Berlin.” Antipode 44, no. 1 (2012): 239-257. doi:10.1111/j.1467-8330.2011.00861.x. Accessed: Jan. 2018.

Saage, Richard „Wie zukunftsfähig ist der klassische Utopiebegriff?“ UTOPIE kreativ 165/166 (2004): 617-636. http://www.rosa-luxemburg-club.de/fileadmin/rls_uploads/pdfs/165_166-saa ge.pdf. Accessed: July 2017.

St. Hill, Cate. This Is Temporary: How Transient Projects Are Redefining Architecture. Newcastle upon Tyne/UK: RIBA publishing, 2016.

Tonkiss, Fran. "Austerity Urbanism and the Makeshift City.” City 17, no. 3 (2013): 312-324. doi: 10.1080/13604813.2013.795332. Accessed: Jan. 2018. 